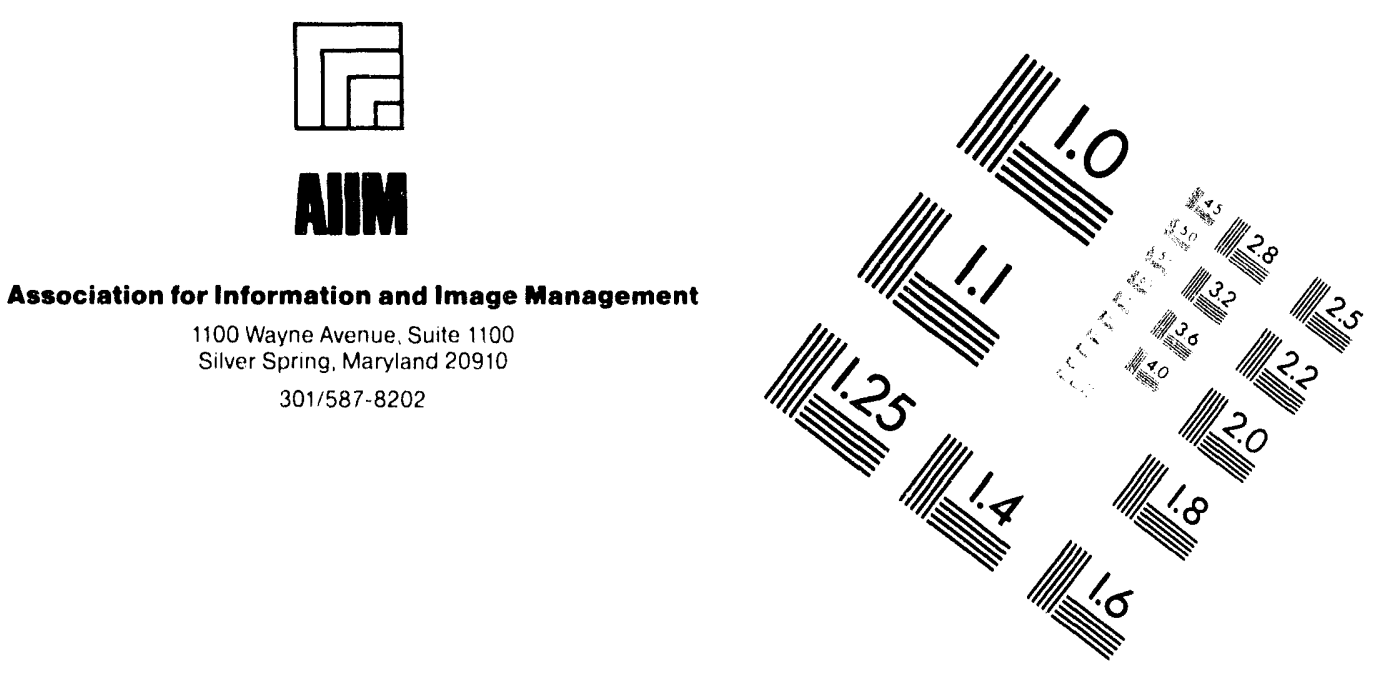

\title{
Centimeter
}

$\begin{array}{llllllllllllllll}1 & 2 & 3 & 4 & 5 & 6 & 7 & 8 & 9 & 10 & 11 & 12 & 13 & 14 & 15 & \mathrm{~mm}\end{array}$

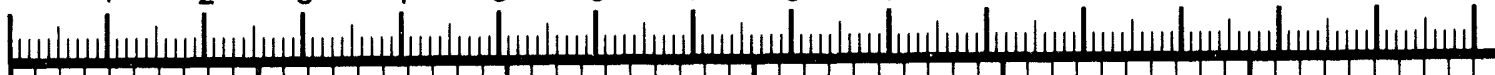

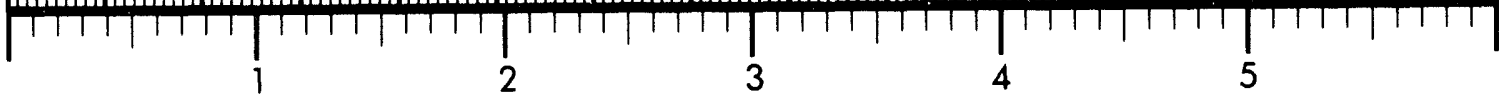
Inches
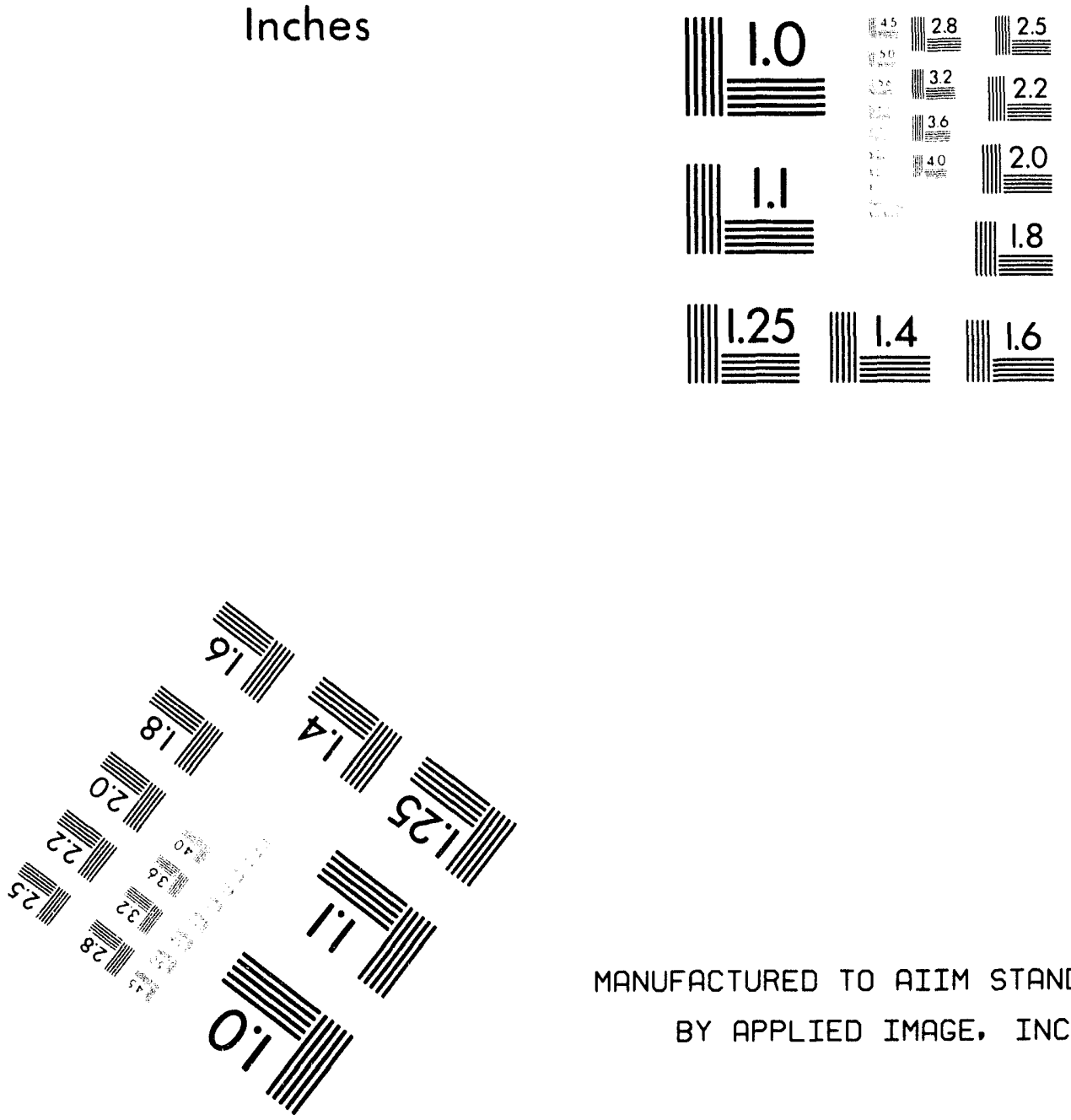

MANUFACTURED TO AIIM STANDARDS BY APPLIED IMAGE. INC.

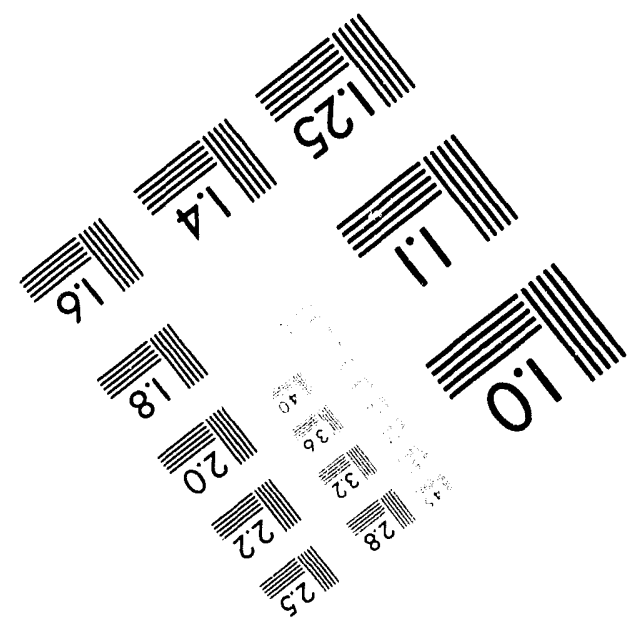



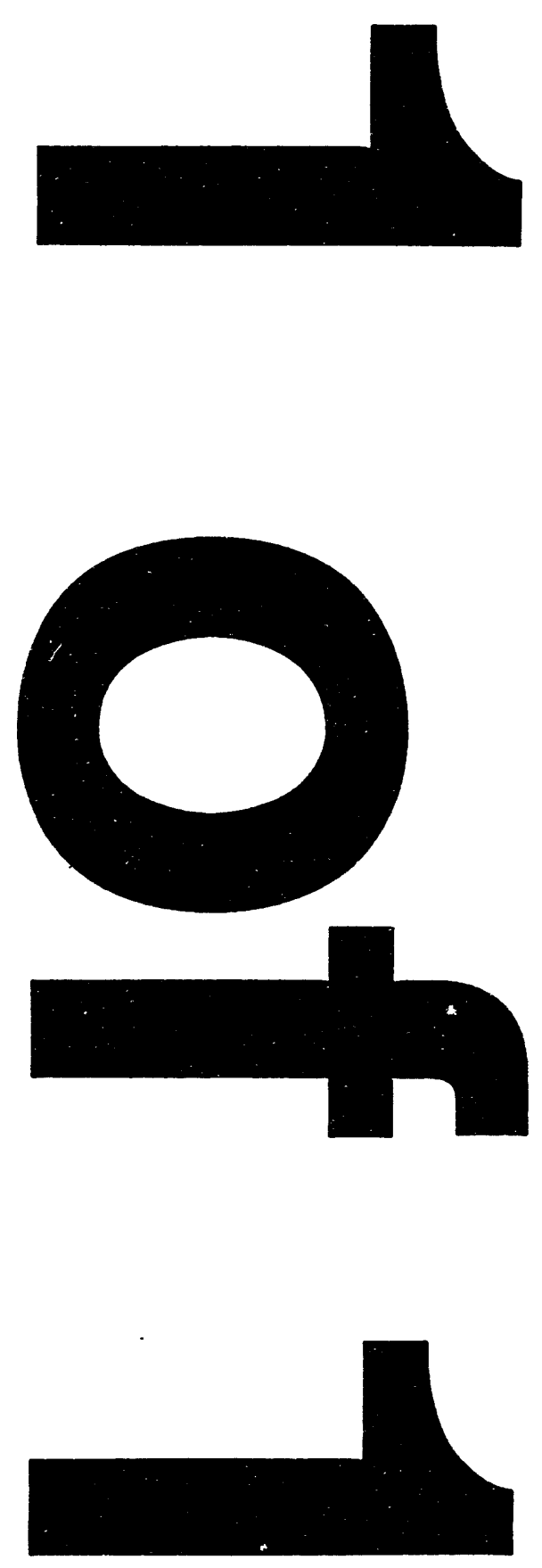


\section{RECENT RESULTS ON THE SOLUBILITY OF URANIUM AND PLUTONIUM IN SAVANNAH RIVER SITE WASTE SUPERNATE}

by

D. G. Karraker

Westinghouse Savannah River Company

Savannah River Site

Aiken, South Carolina 29808

D. T. Hobbs

A document prepared for.

Waste Management '94

at Tucson, $A Z$

from $2 / 27 / 94$ thru $3 / 3 / 94$

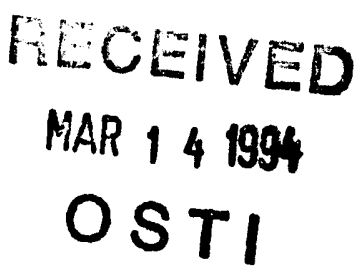

RECEIVED

OSTI

This paper was prepared in connection with work done under the above contract number with the U. S. Department of Energy. By acceptance of this paper, the publisher and/or recipient acknowledges the U. S. Government's right to retain a nonexclusive, royalty-free license in and to any copyright covering this paper, along with the right to reproduce and to authorize others to reproduce all or part of the copyrighted paper. 


\section{DISCLAIMER}

This report was prepared as an account of work sponsored by an agency of the United States Government. Neither the United States Govemment nor any agency thereof, nor any of their employees, makes any warranty, express or implied, or assumes any legal liability or responsibility for the accuracy, completeness, or usefulness of any information, apparatus, product, or process disclosed, or represents that its use would not infringe privately owned rights. Reference herein to any specific commercial product, process, or service by trade name, trademark, manufacturer, or otherwise does not necessarily constitute or imply its endorsement, recommendation, or favoring by the United States Government or any agency thereof. The views and opinions of authors expressed herein do not necessarily state of reflect those of the United States Government or any agency thereof.

This report has been reproduced directly from the best available copy.

Available to DOE and DOE contractors from the Office of Scieatific and Technical Information, P. O. Box 62, Oak Ridge. TN 37831; prices available from (615) $576-8401$.

Available to the public from the National Technical Information Service. U. S. Deparment of Commerce, 5285 Port Royal Rd., Springfield, VA 22161 
WSRC-MS-94-061

Waste supernate, U solubility, Pu solubility, Keywords: SRS

RECENT RESULTS ON THE SOLUBILITY OF URANIUM AND PLUTONIUM IN SAVANNAH RIVER SITE WASTE SUPERNATE (U)

D. T. Hobbs and D. G. Karraker

Savannah River Technology Center

Westinghouse Savannah River Co.

Aiken, SC 29808

\section{INTRODUCTION}

High-level waste (HLW) is stored at the Savannnah River site (SRS) in a highly alkaline condition to prevent corrosion of the carbon steel storage tanks. Major components in the liquid phase include nitrate, hydroxide, nitrite, aluminate, carbonate and sulfate. Minor components include chloride, fluoride, oxalate and phosphate. The low solubility of uranium and plutonium in the HLW becomes significant to nuclear safety analyses when the supernate is evaporated to solids to conserve waste storage space and then redissolved to process for permanent disposal. The study of uranium and plutonium solubility in synthetic waste tank solutions was initiated to define actinide behavior during waste removal operations.

\section{BACKGROUND}

Since startup of the site, HLW at the SRS has been processed and stored in underground tanks as shown in Figure 1. Waste, primarily from the Purex, HM and B-Line processes, was neutralized and discharged to the waste tank farm. The base-insoluble solids ("sludge"), which include the actinides and most of the fission products, settle to bottofm of the tank; the supernatant liquid ("supernate") contains ${ }^{137} \mathrm{Cs},{ }^{99} \mathrm{TC}$ in a $5 \mathrm{M} \mathrm{Na}^{+}, 1.4 \mathrm{M} \mathrm{OH}^{\circ}$ salt solution. After decay of the short-lived fission products, the supernate is decanted and evaporated (Tank Farm Evaporator) to reduce its volume. Upon cooling, salts crystallize from the concentrated supernate. Further evaporation of the concentrated supernate crystallizes more salts. This process is continued until the tank is filled. A layer of concentrated supernate is maintained above the crystallized salts.

For permanent disposal, the sludge will be mixed with a borosilicate frit and vitrified in the Defense Waste Processing Facility. To reduce the quantity of glass produced, the sludge is washed (Figure 2) with water to reduce the soluble salt content. sludges high in aluminum will also be treated with ca. $3 \mathrm{M} \mathrm{NaOH}$ and heated to $80^{\circ} \mathrm{C}$. to dissolve the aluminum. These pretreatment steps will be performed in the waste tanks. 
Criticality evaluation of the waste tank evaporation has conjured up two scenarios that caused this investigation of $U$ and $P u$ solubility in the waste supernate. The first scenario involves tanks filled with salt cake, and presumes that during the redissolution of the salt the fissile isotopes do not dissolve, but settle to the bottom of the tank and could potentially form a critical mass. The second scenario considers that $U$ and/or Pu would crystallize in the evaporator during supernate and sludge wash evaporations, and could lead to the accumulation of a critical mass in the evaporator. The study of the solubility of $U$ and $P u$ in the waste supernate was initiated to evaluate these scenarios.

\section{EXPERIMENTAL SECTION}

Synthetic waste solution were prepared from chemically pure reagents; the composition of the average waste supernate is shown in Table 1. Measurements of the concentration öf ürañium in samples were performed by a kinetic fluorescence method ("Chemchek"), by $x$-ray fluorescence ("xrf") and/or inductively coupled plasma/mass spectrometry (ICP/MS). Comparison of the results of the three methods showed substantial agreement. Plutonium was assayed by alpha-counting, coupled with alpha pulseheight analysis to assure the rejection of other alpha-emitting radioactivity, and ICP/MS. Pu was separated from the mass of salts for analysis by anion exchange before counting. Most anions were analyzed by ion chromatography; Al was determined by ICP; carbonate and hydroxide by titration.

Table 1

Composition of synthetic SRS 'Waste supernate and Variable Range Explored in Statistical Design Tests

\section{Component Concentration}

Range Explored in SD Experiment

$\begin{array}{lc}\mathrm{NaOH} & 1.4 \mathrm{M} \\ \mathrm{NaNO}_{3} & 2.4 \mathrm{M} \\ \mathrm{NaNO}_{2} & 0.9 \mathrm{M} \\ \mathrm{NaAlO}_{2} & 0.5 \mathrm{M} \\ \mathrm{Na}_{2} \mathrm{CO}_{3} & 0.2 \mathrm{M} \\ \mathrm{Na}_{2} \mathrm{SO}_{4} & 0.2 \mathrm{M} \\ \mathrm{NaCl} & 0.03 \mathrm{M} \\ \mathrm{KF} & 0.02 \mathrm{M} \\ \mathrm{Na}_{2} \mathrm{C}_{2} \mathrm{O}_{4} & 0.02 \mathrm{M} \\ \mathrm{Na}_{3} \mathrm{PO}_{4} & 0.01 \mathrm{M}\end{array}$

$$
\begin{aligned}
& 0.5-2.0 \mathrm{M} \\
& 1.0-4.0 \mathrm{M} \\
& 0.1-2.0 \mathrm{M} \\
& 0.05-0.36 \mathrm{M} \\
& 0.02-0.30 \mathrm{M} \\
& 0.02-0.40 \mathrm{M}
\end{aligned}
$$

(a)

(a)

(a) Not included in statistical design $25^{\circ}, 60^{\circ} \mathrm{C}$

(a) Not included in statistical design tests

Uranium and plutonium were added to synthetic waste solutions by the "undersaturation" (addition of a concentrated solutions of U and $\mathrm{Pu}$ to the test solutions) in the SD tests, and by "oversaturation" (mixing a dilute acidic solution with a solution of the basic components) in the evaporation experiments. Test solutions were agitated betweeen sampling; samples were filtered 
through 0.45 or $0.2 \mu$ syringe filters before analyses. Particle sizes were determined with a Microtrack II laser scattering instrument.

Statistical design measurements were carried out over a 6-month period although the change from the first to the last sample of a particular solution was usually within a factor of two, and occasionally identical. Samples from evaporation and/redissolution experiments were usually analyzed within a week of sampling.

\section{Results}

The particle sizes of precipitated $U$ was found to be considerably larger from the undersaturation than the oversaturation method of addition; after 16 hours stirring $10 \%$ of the solids were $<3.3 \bar{\mu}, 50 \%$ $<18 \mu$ and $90 \%<60 \mu$ from undersaturated solutions. The comparable values for oversaturated solutions were $10 \%<2.3 \mu, 50 \%<3.8 \mu$ and $90 \%<13 \mu$. Solids from a neutralized synthetic High Activity Waste Concentrate (HAWC) had approximately the same size distribution as the solids from oversaturated solutions.

\section{Statistijal Design Experiments}

Solubilities from the statistical design tests were investigated to screen for significant: factors and interactions among the components (Table 1) of the salt solutions. Over the range of hydroxide concentrations from 0.5 to 2.0 molar, the uranium solubility ranges from 2 to $10 \mathrm{mg} / \mathrm{L}$ (see Figure 3). The solubility of plutonium is lower, ranging from 0.01 to $1.0 \mathrm{mg} / \mathrm{L}$. Note however, that at the bounding hydroxide concentrations, the plutonium and uranium concentration can vary by factors of between 3 and 30 depending on the concentrations of the other solution constituents.

Linear statistical models were developed from the results to allow prediction of solubilities within the range of variables investigated. Abbreviated equations are:

$\mathrm{Pu}(\mathrm{mg} / \mathrm{L})=0.58\left[\mathrm{CO}_{3}\right]-0.35\left[\mathrm{SO}_{4}\right]+0.70[\mathrm{OH}]\left[\mathrm{SO}_{4}\right]+0.09[\mathrm{OH}]\left[\mathrm{NO}_{2}\right]$ $+0.06\left[\mathrm{NO}_{3}\right]\left[\mathrm{NO}_{2}\right]-0.10[\mathrm{OH}]\left[\mathrm{NO}_{3}\right]\left[\mathrm{NO}_{2}\right]$

$\mathrm{U}(\mathrm{mg} / \mathrm{L})=3.02+0.48\left[\mathrm{NO}_{3}\right]-0.90\left[\mathrm{NO}_{2}\right]+3.91[\mathrm{OH}]-4.81\left[\mathrm{CO}_{3}\right]-$ $0.92[\mathrm{OH}]\left[\mathrm{NO}_{3}\right]$

(Brackets [] denote molar units.)

Temperature was found to have an insignificant effect on the solubilities. For salt solutions within the range of the statistical design study, upper 958 tolerance limits for $\mathrm{Pu}$ and $\mathrm{U}$ are $1.7 \mathrm{mg} / \mathrm{L}$ and $17 \mathrm{mg} / \mathrm{L}$, respectively.

Figure 4 shows a plot of plutonium solubility as a function of 
hydroxide concentration for the factorial design test and available literature data. A quadratic model was fitted to the expression

$$
\log [\mathrm{Pu}]=-6.493+1.270 \log [\mathrm{OH}]+0.505(\log [\mathrm{OH}])^{2}
$$

Because of the wide range of solution compositions, the solubility of plutonium can vary by as much as three orders of magnitude for any given hydroxide concentration and remain within the prediction interval. Additional tests are planned to determine the solubility of plutonium at lower hydroxide concentrations and also to determine the effects of coprecipitation with metal ions such as iron, manganese, nickel and aluminum.

\section{Evaporation Studies}

Simulated evaporator experiments involved evaporation of the a synthetic average waste supernate solution (Table 1), sampling the solution as the evaporation proceeded. During the course of the evaporation, salts crystallized from the solution, and thus the composition of the solution changed. Figures 5 and 6 show the composition of the solution as the salts crystallize. Concentration of sludge washing solutions was simulated by assuming that the decantation of supernate from sludge would leave a substantial heel of supernate to $\mathrm{mix}$ with the sludge washing solution. Succeeding sludge washes would then contain lesser amounts of supernate. Evaporation of sludge washes was simulated by evaporating mixtures of supernate and $1 \mathrm{M} \mathrm{NaOH}$.

The solubility of $U$ during evaporation is summarized in Figures 7 and 8. In general, the solubility of $U$ decreases to a value of 5-10 $\mathrm{mg} / \mathrm{L}$ as the solution is concentrated above $5 \mathrm{M} \mathrm{NaOH}$. Figure 7 shows the data from two evaporations of synthetic supernate; Figure 8 shows the data from evaporation of both synthetic waste supernate and sludge wash-supernate mixtures. The solid phase from several evaporations was identified as " $\mathrm{Na}_{2} \mathrm{U}_{2} \mathrm{O}_{7}$ " by $\mathrm{x}$-ray diffraction.

Redissolution of $U$ with the crystallized salts found a distinctly lower solubility $(2-4 \mathrm{mg} / \mathrm{L})$ than when $U$ was precipitated from solution. Typical data, including attempts to enhance the solubility with complexing agents, is shown in Table 2 . 
Table 2

\section{Dissolving Tests on Salt Cake}

\section{Dissolving Mixing Time solution \\ (days)}

$\mathrm{H}_{2} \mathrm{O}$

$0.2 \mathrm{M} \mathrm{Na}_{2} \mathrm{CO}_{3}$

$0.2 \mathrm{M} \mathrm{Na}_{2} \mathrm{CO}_{3}$

$0.5 \mathrm{M} \mathrm{NaHCO}_{3}$

$0.01 \mathrm{M}$ EDTA

0.001 M EDTA

$\begin{array}{cc}1 & 1.65 \\ 2 & 0.55 \\ 1 & 0.32 \\ 6 & 0.16 \\ 5 & \mathrm{pH} 9 \\ 1 & 3.16 \\ 7 & 2.38\end{array}$

Final Solution Concentration $\mathrm{NaOH}, \mathrm{M} \mathrm{NaAlO}, \mathrm{M} \mathrm{Na}_{2} \mathrm{CO}_{3}, \mathrm{M} \mathrm{U}, \mathrm{mg} / \mathrm{L}$

$\begin{array}{cc}1.65 & 1.44 \\ 0.55 & 0.47 \\ 0.32 & 0.73 \\ 0.16 & 0.37 \\ \mathrm{pH} 9 & 0.58 \\ 3.16 & 1.40 \\ 2.38 & 1.39\end{array}$

0.26

3.8

1.6

1.5

1.8

34

3.2

2.7

The solubility of $\mathrm{Pu}$ during evaporation is shown in Figure " $9, " a$ double-valued curve that suggests that two or more factors influence $\mathrm{Pu}$ solubility. The solubility increases as the evaporation concentrates the solution to about $10 \mathrm{mg} / \mathrm{L}$ at $5 \mathrm{M} \mathrm{NaOH}$. The solubility in mixtures of synthetic supernate and sl udge washes increases as the salt concentration increases (Figure 10). The solid phase in these tests was identified by $x-r a y$ diffraction as $\mathrm{PuO}_{2} \bullet \mathrm{xH}_{2} \mathrm{O}$. The solubility was normally reversible, i.e., dilution of an evaporated solution returned the $\mathrm{Pu}$ concentration to the same value it had before evaporation.

\section{DISCUSSION}

The major finding of these studies is that as supernate solutions are evaporated, $U$ becomes less soluble, and $\mathrm{Pu}$ becomes more soluble. The presumption of accumulation is therefore more credible for $U$ than for $\mathrm{Pu}$, although the location of the accumulation--evaporator, sludge, or salt--will depend on physical factors, such as particle size, mixing, and equipment geometry. The solubility results conform with the fesults from an acid cleanout of the West valley waste evaporator. The acid washes removed $10.1 \mathrm{Kg} \mathrm{U}$ and $255 \mathrm{~g} \mathrm{Pu}$, indicating a substantial accumulation of $\mathrm{U}$ but an insignificant accumulation of $\mathrm{Pu}$.

The difference between $U$ solubility on precipitation and redissolution indicates that under the conditions of these experiments, $U$ solubility is not an equilibrium process, and thus is influenced by manner of precipitation, particle size, etc. as well as by the composition of the solution. A possible explantaion might be found in the complex nature of the solid phase, which has been formulated as $3 \mathrm{Na}_{2} \mathrm{O} \cdot 7 \mathrm{UO}_{3}$ by Wamser, et.al.?, and $\mathrm{Na}_{2} \mathrm{O} \cdot 6 \mathrm{UO}_{3}$ by Ricci and Loprest. The latter propose that there are solid solutions of $\mathrm{Na}_{2} \mathrm{O}$ in $\mathrm{UO}_{3}$ with $\mathrm{Na} / \mathrm{U}$ ratios from $8 / 11$ to $1 / 3$. The soluble species have been deduced ${ }^{3}$ as polymeric species such as $\mathrm{U}_{2} \mathrm{O}_{5}{ }^{2-}, \mathrm{U}_{3} \mathrm{O}_{8}{ }^{++}$and $\mathrm{U}_{3} \mathrm{O}_{8}(\mathrm{OH})^{+}$. The kinetic path between the solution polymer and the solid polymer may depend on the transfer of $U$ via species of low concentration, and thus might require a lengthy period to attain equilibrium. 
Plutonium solubility appears to be readily reversible, indicating an equilibrium between the species in solution and the solid phase. The decreasing solubility as $\mathrm{NaOH}$ increases below $2 \mathrm{M} \mathrm{NaOH}$ is consistent with a $\mathrm{Pu}(\mathrm{OH})_{4} \cdot \mathrm{xH}_{2} \mathrm{O}$ species, but the increase in solubility with increasing $\mathrm{NaOH}$ above $2 \mathrm{M}$ NaOH suggests that another factor has come into play. A conceivable explanation for this phenomenon is the air oxidation of some of the Pu from the IV valence to the more soluble $V$ or $V I$ state either by

$$
4 \mathrm{PuO}_{2} \cdot \times \mathrm{H}_{2} \mathrm{O}+\mathrm{O}_{2}+2 \mathrm{H}_{2} \mathrm{O}-\cdots 4 \mathrm{PuO}_{2}(\mathrm{OH})+(x-2) \mathrm{H}_{2} \mathrm{O}
$$

possibly followed by

$2 \mathrm{PuO}_{2}(\mathrm{OH})--\rightarrow \quad \mathrm{PuO}_{2}+\mathrm{PuO}_{2}(\mathrm{OH})_{2}$

or directly, as $\mathrm{PuO}_{2} \cdot \times \mathrm{H}_{2} \mathrm{O}+\mathrm{O}_{2}+2 \mathrm{H}_{2} \mathrm{O}=-->2 \mathrm{PuO}_{2}(\mathrm{OH})_{2}$.

Evidence has been adduced for $\mathrm{Pu}(\mathrm{V})$ as a stable species in highly basic solutions. Pu(V) species have been produced by electrolytic reduction of $\mathrm{Pu}(\mathrm{VI})$ in $4 \mathrm{M} \mathrm{NaOH}$, and the absorption spectra of $\mathrm{Pu}(\mathrm{V})$ measured ${ }^{5}$. Delegard $d^{6}$ has published absorption spectra for Pu in 15M $\mathrm{NaOH}$ that agrees with this spectra, and reports an experiment in a $10 \mathrm{M} \mathrm{NaOH} \mathrm{Pu}$ solution that can be interpreted as demonstating either a V-VI or a IV-VI mixture. Other studies, however, predict that $\mathrm{Pu}(\mathrm{V})$ would disproportionate in strong base to a mixture of $\mathrm{Pu}(\mathrm{IV})$ and $\mathrm{Pu}(\mathrm{VI}){ }^{7,8}$.

Assignment of a $\mathrm{Pu}(\mathrm{V})$ valence to the $\mathrm{Pu}$ in the supernate rests on the determination of $\mathrm{Pu}(\mathrm{V})$ stability in strong ( $>2 \mathrm{M}) \mathrm{NaOH}$, and the assumption that the valence is the same in $\mathrm{NaOH}$ and $\mathrm{NaOH}-\mathrm{salt}$ solutions. As Figure 7 shows, the solubility is strongly affected by the presence of the salts, and the possibility of a change in valence from the expected $\mathrm{Pu}(\mathrm{V})$ cannot be discounted.

Speciatior of the $\mathrm{Pu}$ in these solutions could resolve question of $\mathrm{Pu}$ valence, but the presence of high levels of nitrite in the supernate prevents the use of simple chemical methods, such as solvent extraction or anion exchange from acidified solutions. On acidification, nitrite converts all $\mathrm{Pu}$ present to $\mathrm{Pu}(\mathrm{IV})$, and thus the identity of the valence in the basic solutions is lost.

One factor that has not been explored in this study is the effect of the $4 \times 10^{4} \mathrm{R} / \mathrm{h}$ radiation in the waste tanks. The free radicals generated by this radiation field could affect the valence of $\mathrm{Pu}$ in the actual waste supernate, and thus affect the solubility. Uranium solubilitywould not be expected to be affected by radiation, since the lower valences of uranium are oxidized to the uranyl valence by air alone in a basic system. A preliminary experiment indicates that the solubility of $\mathrm{Pu}$ is increased four-fold by exposure in a ${ }^{60} \mathrm{co}$ source for 6 days. Further studies are in progress; in the meantime, $\mathrm{Pu}$ solubility in actual waste supernate remains in question. 
References

1. G. Smith, West Valley, FAX to T. Hsu, SRS. "Acid Cleaning Data" 26 August 1991.

2. C.A. Wamser, J. Belle, E. Bernsohn, and B. Williamson, JACS, 74,1028 (1952).

3. J. E. Ricci and F. J. Loprest, JACS, 77, 2119 (1955).

4. J. Sutton, J. Chem. Soc. 1949, S275

5. J. Bourges, Radiochem. and Radioanal. Letters, 12, 111 (1972).

6. C. H. Delegard, Radiochim. Acta, 41, 11 (1987).

7. H. Capdevilla, P. Vitorge and E. Giffaur, Radiochim. Acta, 58, 45 (1992).

8. H. Nitsche, A. Müller, E. M. Standifer, R. S. Deinhammer, K. Becraft, T. Prussin and R. C. Gatti, Radiochim. Acta, 58, 45 (1992). 


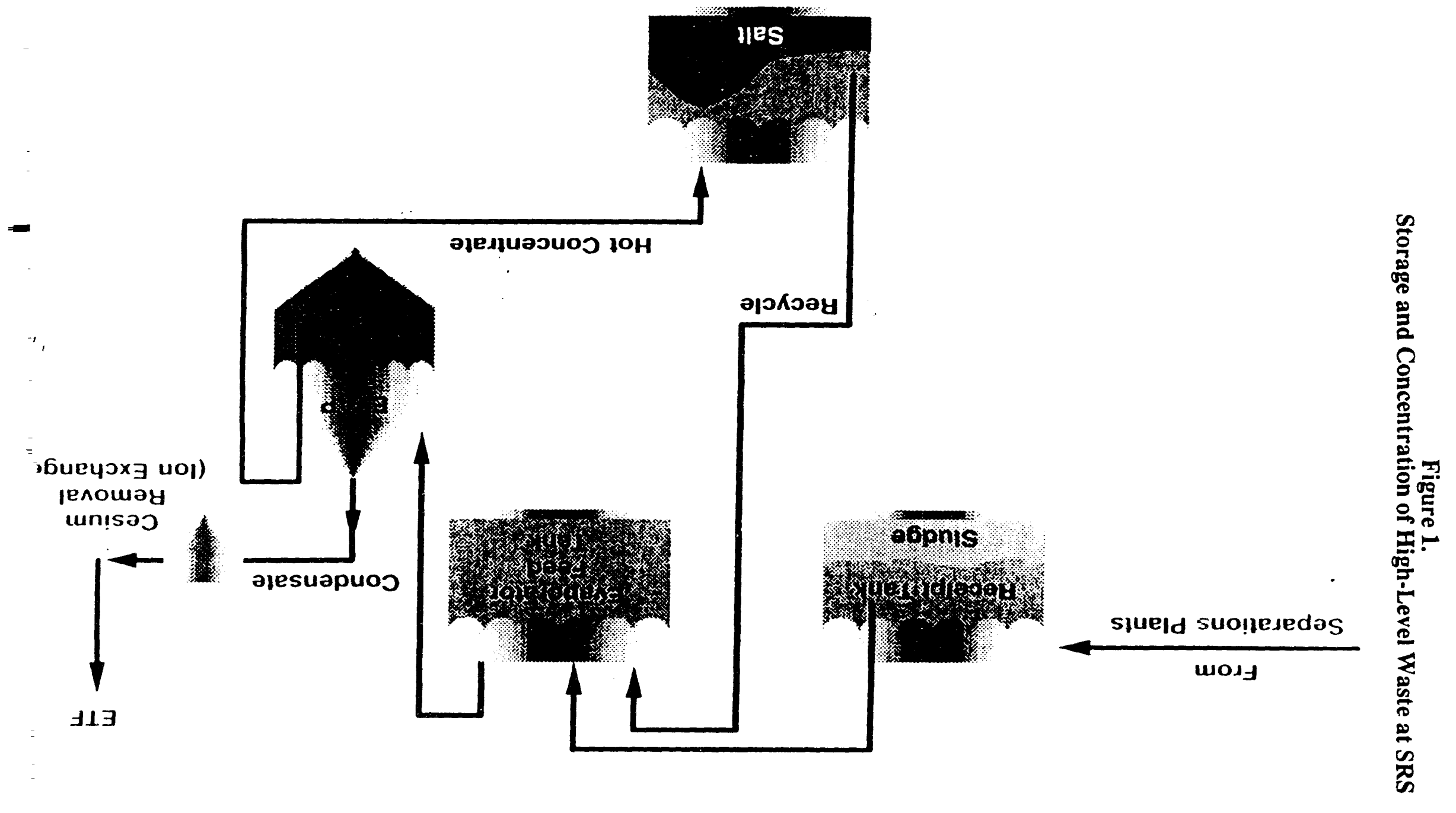

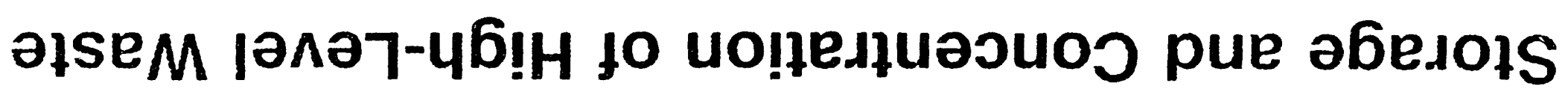




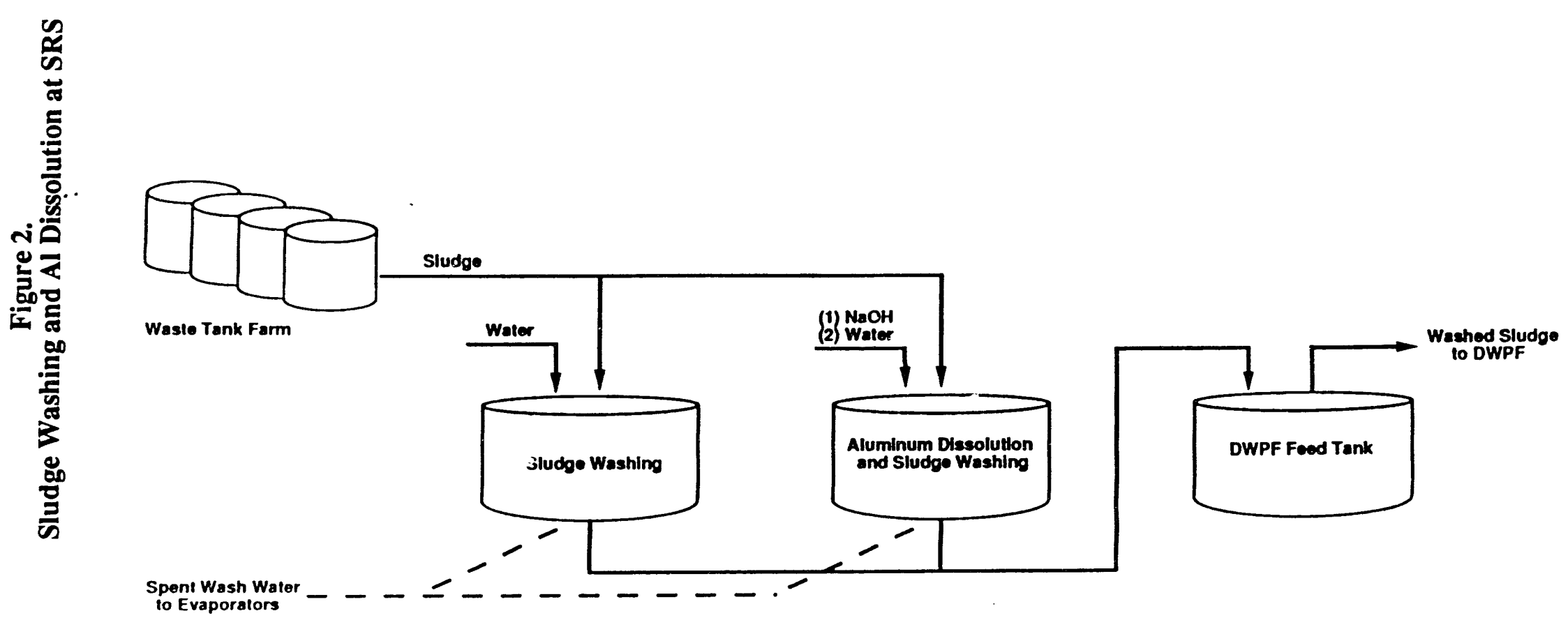


Concentration (mg/L)

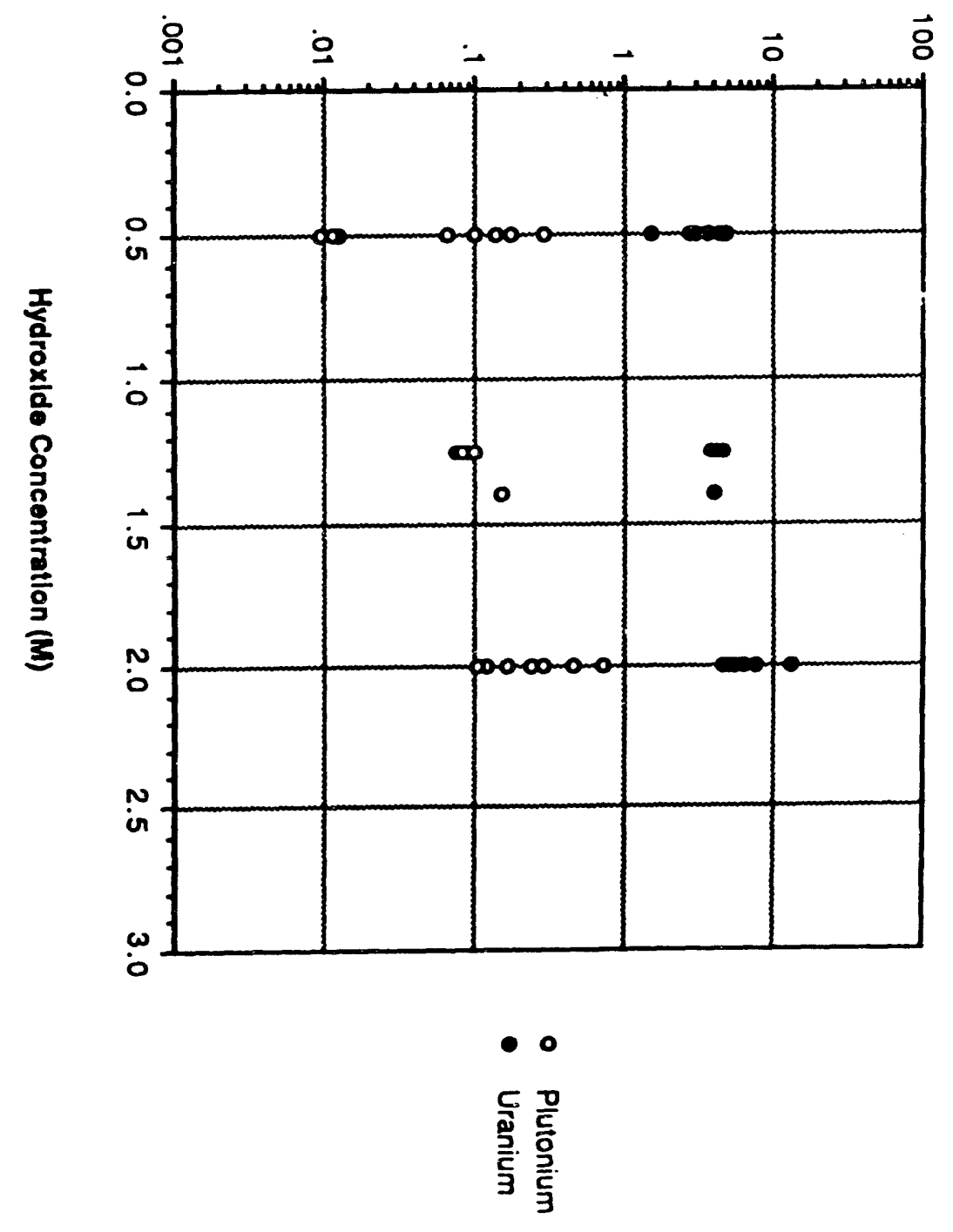

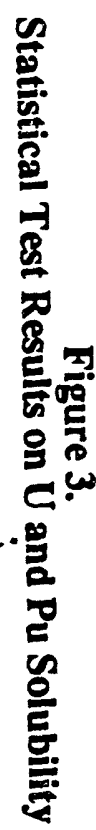


Figure 4:

Pu Solubility in Hydroxide Solutions

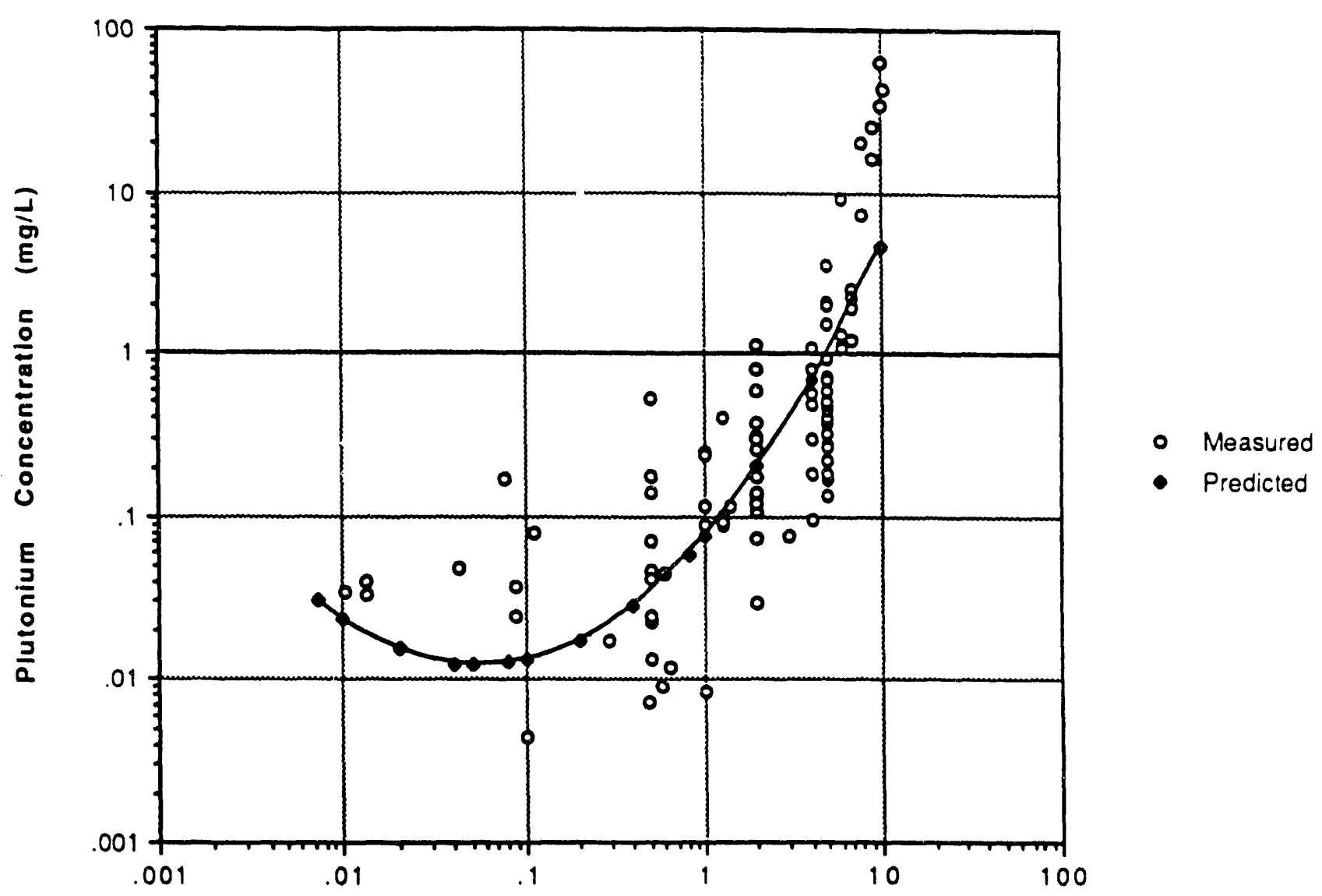

Hydroxide Concentration (M) 
Figure 5

Synthetic Waste Supernate Major Species Concentration during Evaporation

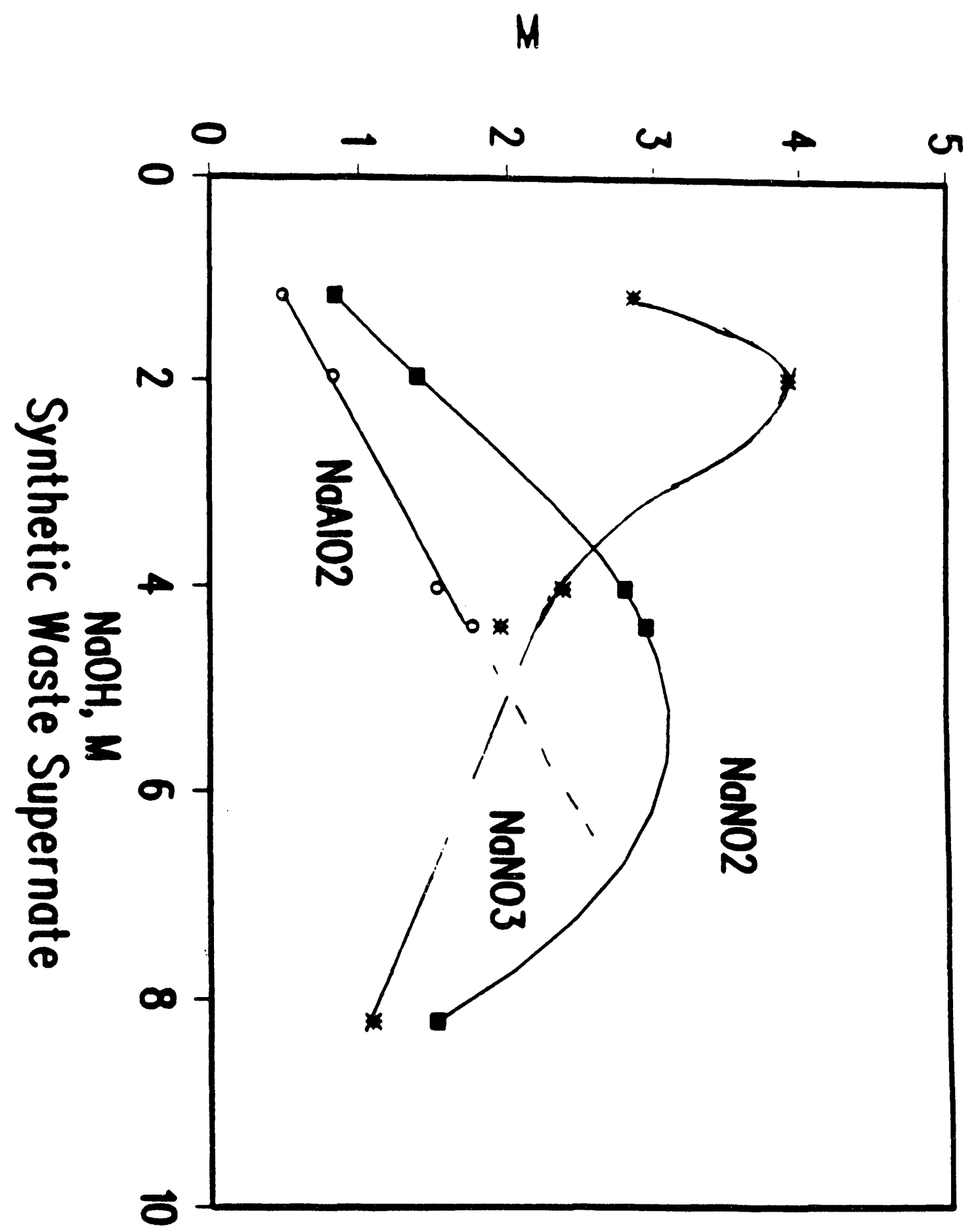


Figure 6.

Synthetic Waste Supernate Minor Species Concentration during Evaporation

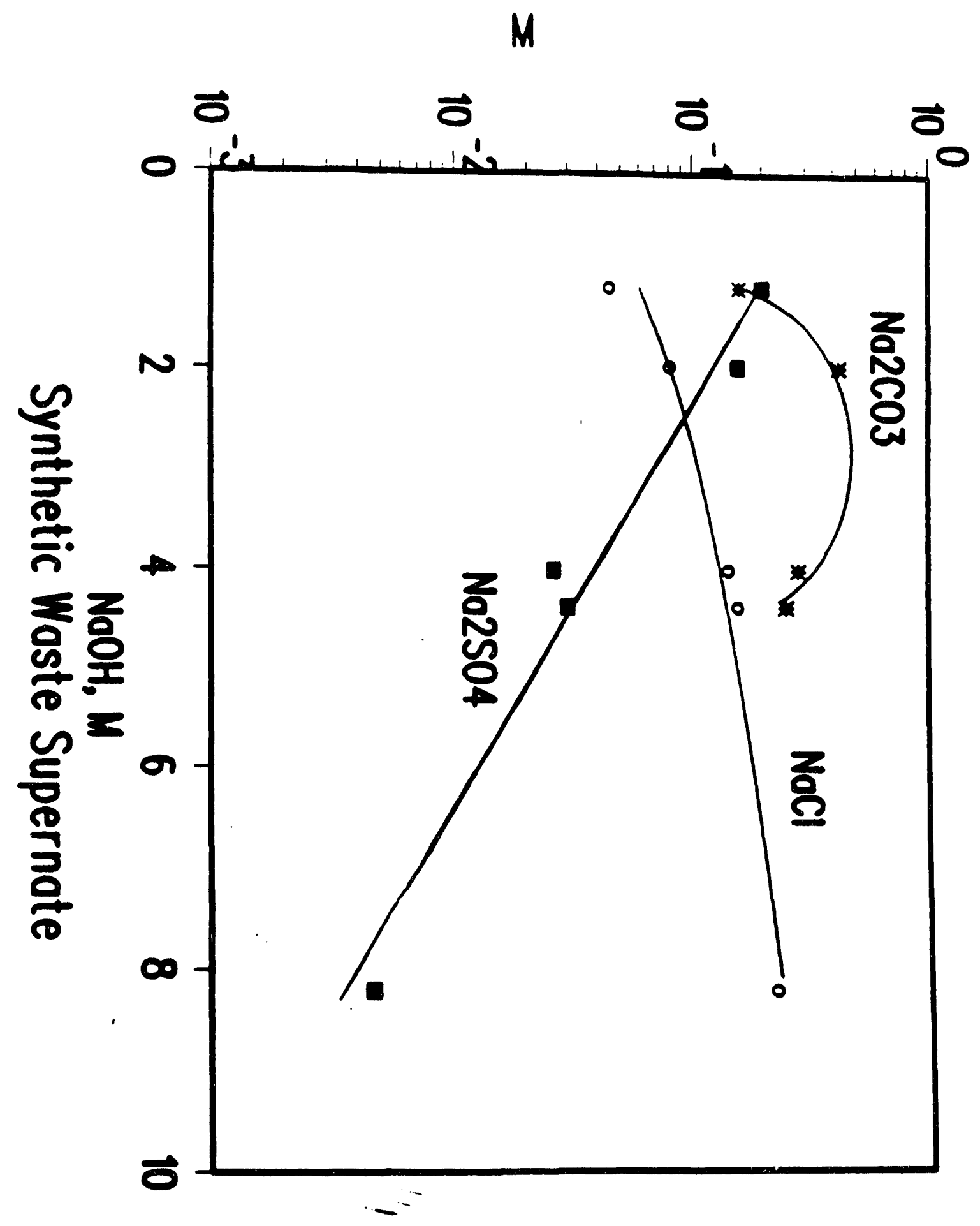


Figure 7.

U Solubility in Synthetic Waste Supernate

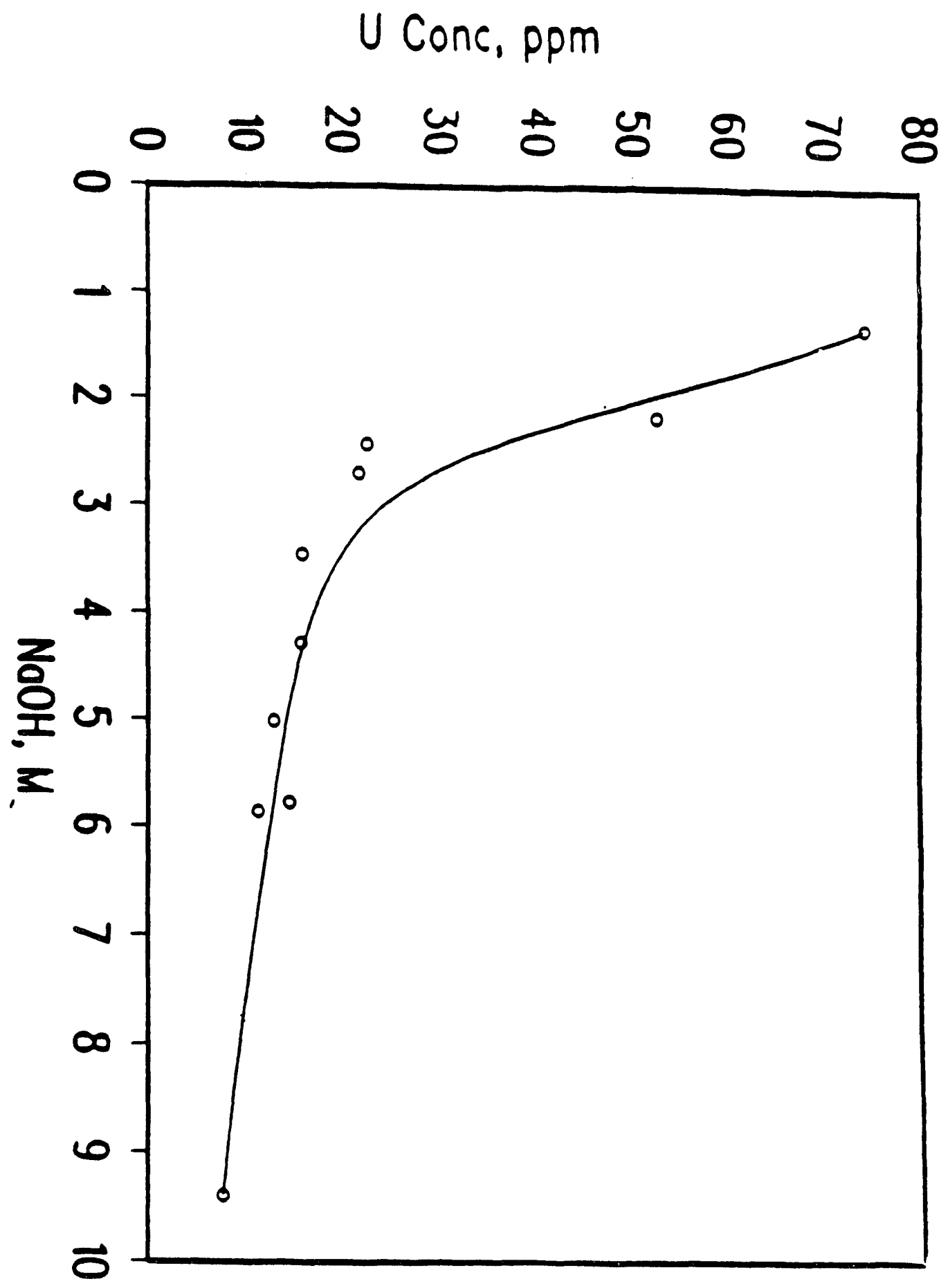




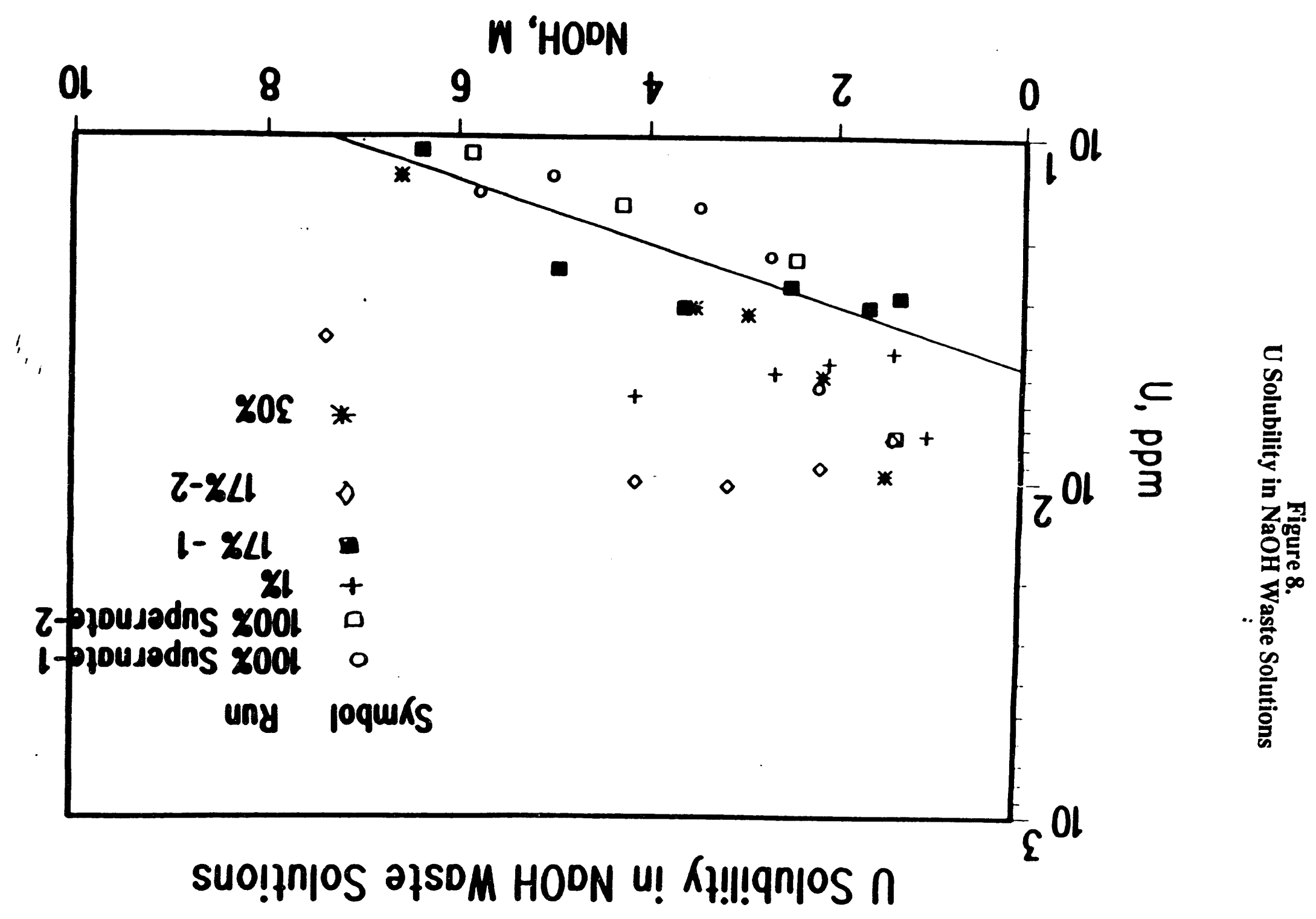




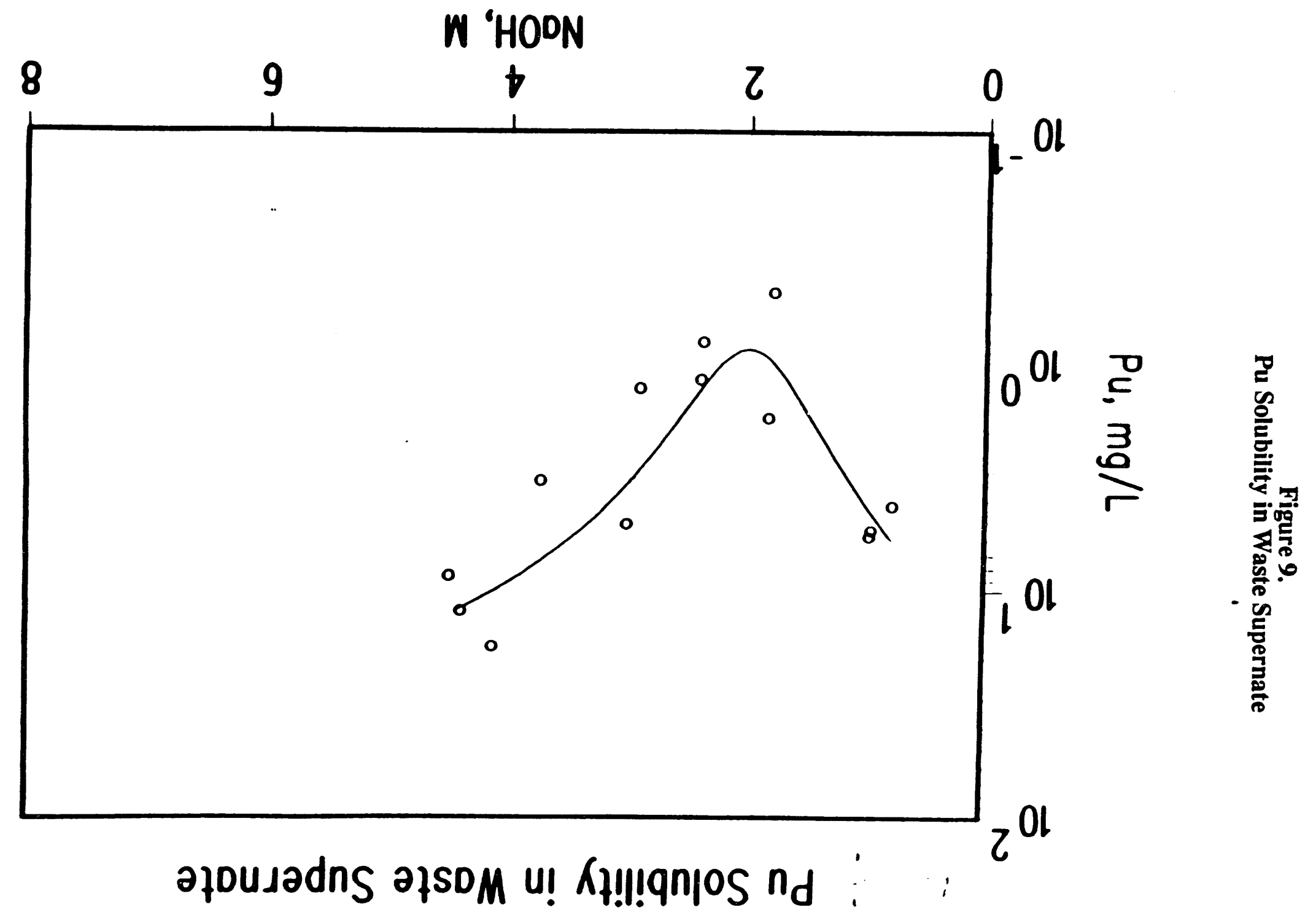




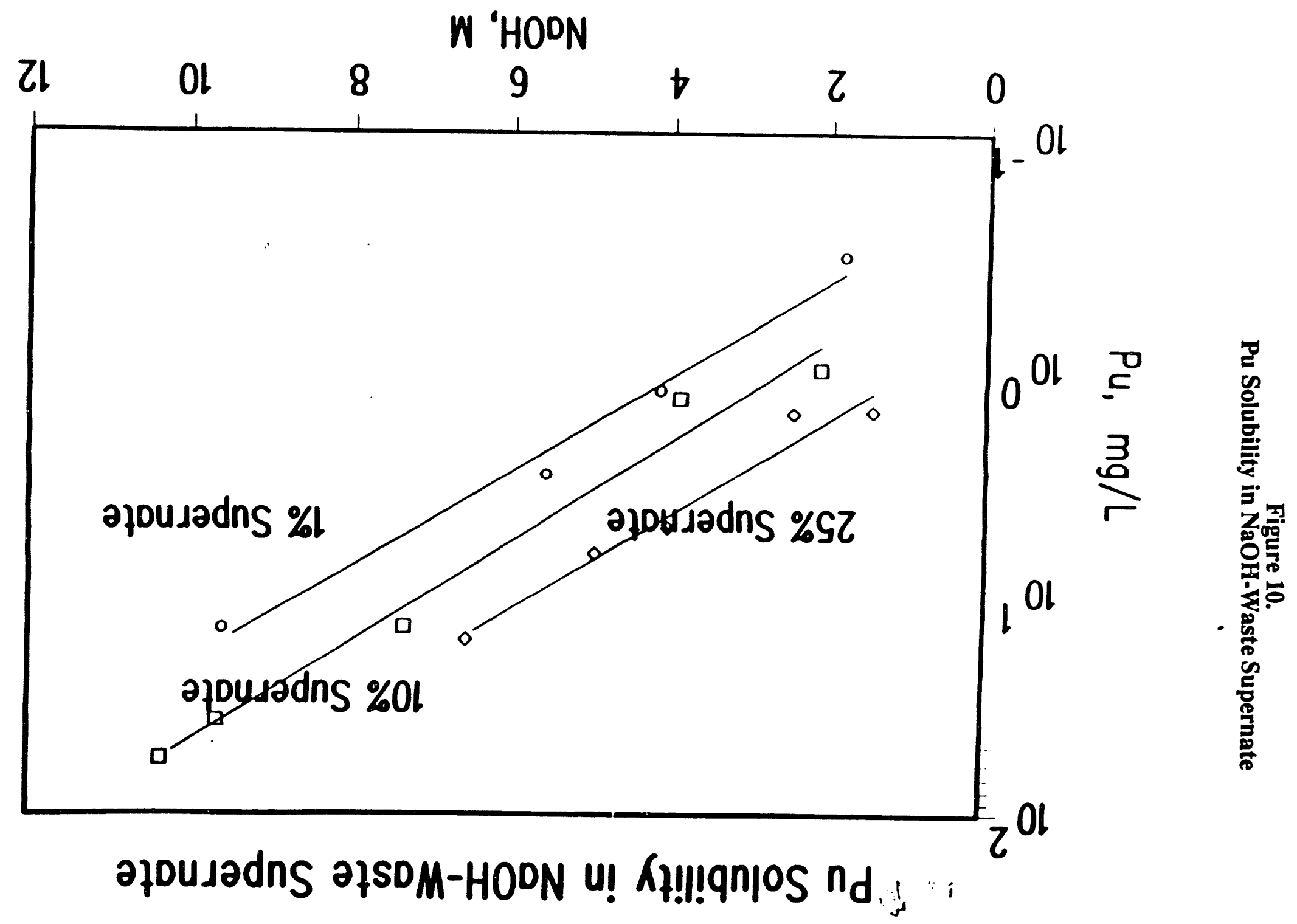



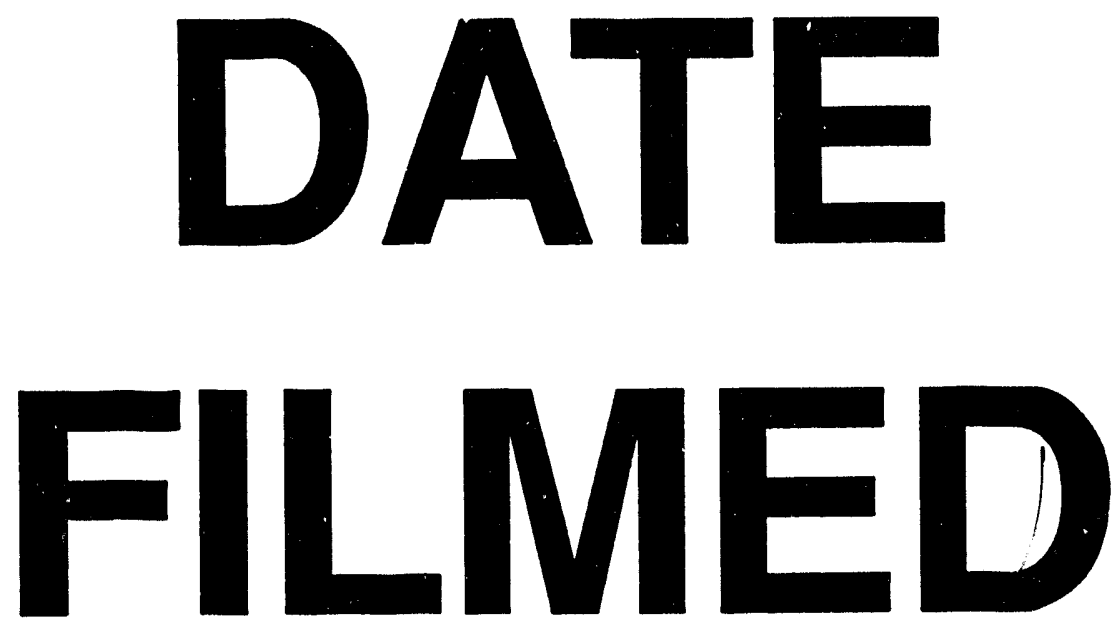

$6 / 29 / 94$
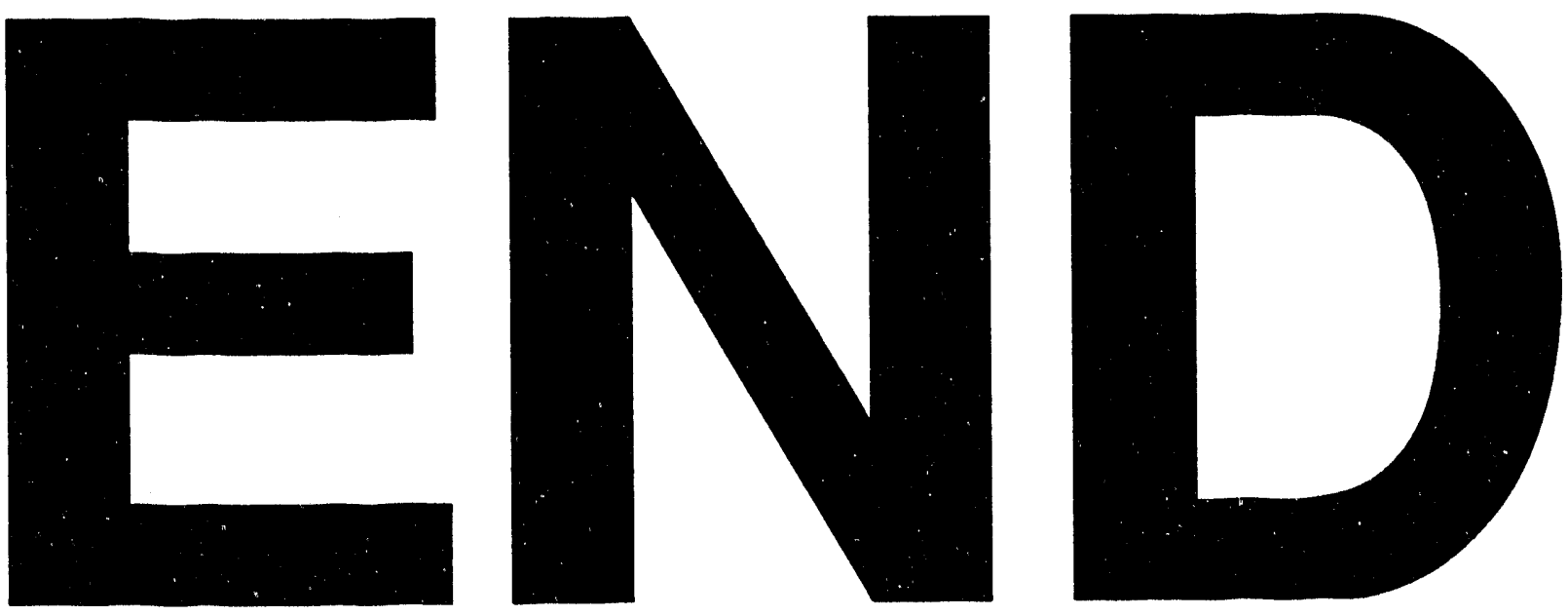
